\title{
Nitrogen fixation and transfer in open ocean diatom-cyanobacterial symbioses
}

\author{
Rachel A Foster ${ }^{1,2}$, Marcel MM Kuypers ${ }^{2}$, Tomas Vagner², Ryan W Paerl ${ }^{1}$, Niculina Musat ${ }^{2}$ \\ and Jonathan $\mathrm{P} \mathrm{Zehr}^{1}$ \\ ${ }^{1}$ Ocean Sciences Department, University of California, Santa Cruz, CA, USA and ${ }^{2}$ Department of \\ Biogeochemistry, Max Planck Institute for Marine Microbiology, Bremen, Germany
}

\begin{abstract}
Many diatoms that inhabit low-nutrient waters of the open ocean live in close association with cyanobacteria. Some of these associations are believed to be mutualistic, where $\mathrm{N}_{2}$-fixing cyanobacterial symbionts provide $\mathrm{N}$ for the diatoms. Rates of $\mathrm{N}_{2}$ fixation by symbiotic cyanobacteria and the $\mathrm{N}$ transfer to their diatom partners were measured using a high-resolution nanometer scale secondary ion mass spectrometry approach in natural populations. Cell-specific rates of $\mathrm{N}_{2}$ fixation (1.15-71.5 fmol $\mathrm{N}$ per cell $\mathrm{h}^{-1}$ ) were similar amongst the symbioses and rapid transfer (within $30 \mathrm{~min}$ ) of fixed $\mathrm{N}$ was also measured. Similar growth rates for the diatoms and their symbionts were determined and the symbiotic growth rates were higher than those estimated for free-living cells. The $\mathrm{N}_{2}$ fixation rates estimated for Richelia and Calothrix symbionts were 171-420 times higher when the cells were symbiotic compared with the rates estimated for the cells living freely. When combined, the latter two results suggest that the diatom partners influence the growth and metabolism of their cyanobacterial symbionts. We estimated that Richelia fix $81-744 \%$ more $\mathrm{N}$ than needed for their own growth and up to $97.3 \%$ of the fixed $\mathrm{N}$ is transferred to the diatom partners. This study provides new information on the mechanisms controlling $\mathbf{N}$ input into the open ocean by symbiotic microorganisms, which are widespread and important for oceanic primary production. Further, this is the first demonstration of $\mathrm{N}$ transfer from an $\mathrm{N}_{2}$ fixer to a unicellular partner. These symbioses are important models for molecular regulation and nutrient exchange in symbiotic systems. The ISME Journal (2011) 5, 1484-1493; doi:10.1038/ismej.2011.26; published online 31 March 2011

Subject Category: microbe-microbe and microbe-host interactions
\end{abstract}

Keywords: nanoSIMS; symbioses; cyanobiont; diatoms; $\mathrm{N}_{2}$ fixation

\section{Introduction}

It is well established that oceanic $\mathrm{N}_{2}$ fixation has a pivotal role in providing 'fixed' nitrogen $(\mathrm{N}$; new production) to surface water communities (Karl et al., 1997, 2002). However, there is a continuing controversy regarding the apparent imbalance in the sources and sinks of $\mathrm{N}$ in the global $\mathrm{N}$ budget (Codispoti, 1995; Michaels et al., 1996; Gruber, 2005). Many studies over the last decade have shown the presence and activity of diverse $\mathrm{N}_{2}$-fixing microorganisms (Zehr et al., 1998, 2000; Montoya et al., 2004), and so it has also been argued that $\mathrm{N}$ input from these other $\mathrm{N}_{2}$-fixing microorganisms (that is, unicellular groups) have been underestimated. Furthermore, there is new evidence strongly suggesting a methodological underestimation of oceanic $\mathrm{N}_{2}$ fixation rates by standard isotope tracer experiments (Mohr et al., 2010). A unique group of

Correspondence: R Foster, Department of Biogeochemistry, Max Planck Institute for Marine Microbiology, Celsiusst. 1, MPI for Marine Microbiology, D-28359 Bremen, Germany.

E-mail: rfoster@mpi-bremen.de

Received 16 November 2010; revised 8 February 2011; accepted 8 February 2011; published online 31 March 2011 open ocean diazotrophs, which have been understudied, including their $\mathrm{N}_{2}$-fixing activities, are the heterocystous cyanobacteria that live symbiotically with other phytoplankton, primarily diatoms.

Richelia intracellularis and Calothrix rhizosoleniae are filamentous heterocystous cyanobacteria that live in presumed symbioses with several diatom genera, including Hemiaulus, Rhizosolenia and Chaetoceros (Figures 1a-c; see also illustrations of diatom ultrastructure in Tomas, 1997). Heterocysts are specialized cells in which $\mathrm{N}_{2}$ fixation is localized (Stewart, 1973), and therefore it is assumed that the cyanobacterial symbionts provide fixed $\mathrm{N}$ to the diatom partners. Richelia spp. and Calothrix spp. have morphologically similar filaments, called trichomes, comprised of vegetative cells and a terminal heterocyst. The length, location and number of Richelia and Calothrix trichomes per diatom partner, and phylogeny of the symbionts differ in each symbiosis (Janson et al., 1999; Foster and Zehr, 2006). There is another less studied symbiosis between the chain-forming pennate diatom, Climacodium frauenfeldianum and unicellular cyanobacteria similar in morphology to the free-living diazotroph, Crocosphaera watsonii (Figure 1d). A recent re-evaluation of the partial 

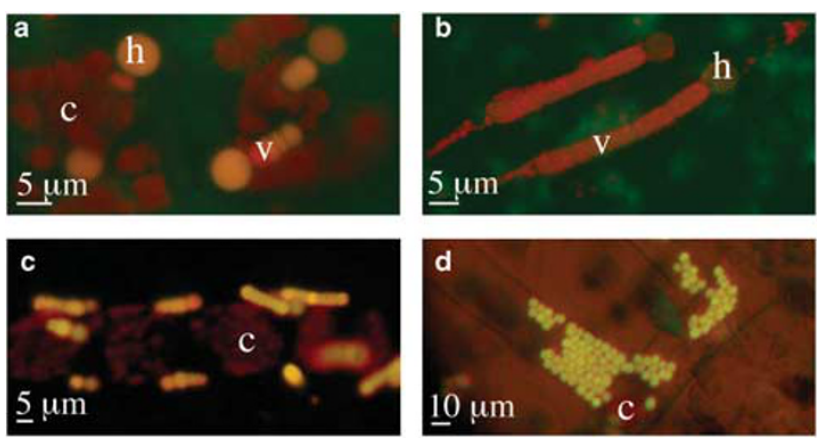

Figure 1 Blue light excitation (450-490 nm) images of field collected diatom-cyanobacteria symbioses. The diatom frustules are not easily seen under epi-fluorescence microscopy (except in d), however, the excitation patterns of the cyanobacterial symbionts are clearly different and yellow/orange from their diatom partners (red). (a) Two Hemiaulus membranaceus diatoms with two Richelia intracellularis associated to each diatom. The chlorophyll a within the chloroplast (c) of the diatom fluoresces red, whereas the pigments in the vegetative (v) cells and the terminal heterocyst (h) of Richelia fluoresce yellow-orange. (b) The apical end of a Rhizosolenia clevei diatom with two associated trichomes of $R$. intracellularis (c) A chain of Chaetoceros spp. diatoms with Calothrix rhizosoleniae attached to the spines (not visible). (d) A chain of Climacodium frauenfeldianum diatoms associated with yellow-fluorescing unicellular cyanobacteria (cyanobionts).

16S rRNA sequence derived from a symbiotic C. frauenfeldianum reported by Carpenter and Janson (2000), found $100 \%$ sequence identity to C. watsonii 8501 (personal communication, Shellie Bench). The benefit (or costs) of the symbiotic relationship for either partner has not been clearly characterized in any of the diatom-cyanobacterial symbioses, but a primary interaction has been assumed to be provision of fixed $\mathrm{N}$ to the diatom by the potentially $\mathrm{N}_{2}$-fixing symbiont.

The symbiotic diatoms have been observed in all the major ocean basins (see review, Foster and O'Mullan 2008), where bloom cell densities have been reported (Villareal, 1994; Carpenter et al., 1999), however, there are few reported $\mathrm{N}_{2}$ (and carbon (C)) fixation rate measurements for the symbiotic populations. Of the few reported rate measures, estimates were determined from bulk water assays or cell concentrates (plankton slurries) and therefore, the rate estimates include $\mathrm{N}_{2}$ fixation by other co-existing populations, such as Trichodesmium and unicellular cyanobacteria. Recent methodological advancements have made it possible to directly measure and visualize stable isotopes in individual cells (Römer et al., 2006; Clode et al., 2007; Lechene et al., 2007; Ropa et al., 2007; Musat et al., 2008; Finzi-Hart et al., 2009; Halm et al., 2009; Ploug et al., 2010). Using a highresolution nanometer scale secondary ion mass spectrometry (NanoSIMS; Cameca, Gennevilliers Cedex, France) approach we provide the first experimental evidence of $\mathrm{N}_{2}$ fixation and transfer of fixed $\mathrm{N}$ products in field populations of symbiotic diatoms.

\section{Materials and methods}

\footnotetext{
${ }^{15} \mathrm{~N}_{2}$ incubations
}

Two sets of long-term incubation $(0,24,48$ and $76 \mathrm{~h})$ experiments were run in July 2008 at two locations in the Gulf of California $\left(2123{ }^{\circ} \mathrm{N}, 107.05{ }^{\circ} \mathrm{W}\right.$ and $2449{ }^{\circ} \mathrm{N}, 10900{ }^{\circ} \mathrm{W}$ ) and one location in the subtropical North Pacific $\left(244^{\circ} \mathrm{N}, 15827.96{ }^{\circ} \mathrm{W}\right)$. In July 2009, one short-term (0,30 min, 1,3 and $12 \mathrm{~h}$ ) set of experiments was performed at the same location of the subtropical North Pacific. Bulk seawater (SW) was collected from 0 to $10 \mathrm{~m}$ using a conductivity temperature depth (CTD) rosette connected to a hydro wire. The $0-10 \mathrm{~m}$ depth was selected, as this was the depth where the most symbiotic diatoms were observed with microscopy.

In July 2008, two experimental designs were used, in which in one design, $4.4 \mathrm{l}$ bottles were filled with bulk SW from the CTD, capped and sealed without air bubbles, and subsequently amended with $3 \mathrm{ml}$ of ${ }^{15} \mathrm{~N}_{2}\left(98 \%+{ }^{15} \mathrm{~N}_{2}\right.$, Cambridge isotopes). In the second design, $5 \mathrm{l}$ of bulk SW was gravity filtered, and the $>5 \mu \mathrm{m}$ cell diameter concentrates were incubated with $200 \mathrm{ml}$ filtered SW, capped, sealed as described above, and amended with $150 \mu \mathrm{l}$ of ${ }^{15} \mathrm{~N}_{2}$. This latter design was used to decrease the time of filtration at the subsequent time points. In July 2009, only $4.4 \mathrm{l}$ bottles were used and treated as described above. All incubations were held at ambient sea surface temperatures by continuously flowing SW and 50\% incident surface irradiance.

At the time of injection (time 0), and at the subsequent time points, the entire contents of incubation bottles were filtered onto a membrane filter using a peristaltic pump and fixed overnight at $4{ }^{\circ} \mathrm{C}$ in (w/v) $100 \mu \mathrm{l}$ of $4 \%$ paraformaldehyde. The July 2008 long-term experiments used 3 or $10 \mu \mathrm{m}$ pore size filters and the July 2009 short-term experiments used $3.0 \mu \mathrm{m}$ pore size filters, which were pre-sputtered with gold $(\mathrm{Au})$ and palladium (Pd). Filters were washed three times in $0.1 \mathrm{M}$ phosphate-buffered saline and stored dry at $-20^{\circ} \mathrm{C}$.

\section{NanoSIMS analyses}

Cells from the July 2008 experiments were resuspended from the $3.0 \mu \mathrm{m}$ pore size membrane filters by gentle pippeting, then filtered onto a $3.0 \mu \mathrm{m}$ pore size Au-Pd sputtered membrane filter and washed with $15 \mathrm{ml}$ of Milli-Q water. This step was omitted for the July 2009 filters, as these were filtered directly onto pre-sputtered filters. A $5 \mathrm{~mm}$ diameter circle was excised in the area on the filter comprised of a few (that is, $>3$ symbioses) symbiotic diatoms and/or free-living cells. Epi-fluorescent images of each free-living cell and diatom-containing symbionts were taken before the nanoSIMS analyses. Once dried, the filters were scanned for diatoms containing Richelia/Calothrix and Climacodium cells with Crocosphaera symbionts, and in 
addition, free-living cells of Richelia, Calothrix and Crocosphaera were also identified using a Zeiss Axioplan (Zeiss, Jena, Germany) epi-fluorescent microscope fitted with blue $(450-490 \mathrm{~nm})$ and green $(510-560 \mathrm{~nm})$ excitation filters. All cells were identified by shape, cell diameter and excitation patterns. In addition, the taper of the trichome was also used to distinguish the Richelia and Calothrix symbionts. Given the 100\% $16 \mathrm{~S}$ rRNA sequence identity between $C$. watsonii 8501 and the partial sequences reported previously from symbiotic Climacodium diatoms (Carpenter and Janson, 2000), we assumed that the unicellular symbionts were Crocosphaera.

For each time point of the long-term incubations (0-76 h), two to three different Hemiaulus-Richelia symbioses were analyzed. For the Climacodium and Chaetoceros diatoms containing symbionts, cells were only re-identified at the initial time (time 0) and at $76 \mathrm{~h}$ time points. We were not able to find these latter symbioses in the 24 and $48 \mathrm{~h}$ time point samples in the long-term experiments of July 2008. Only Hemiaulus-Richelia symbioses, and free-living Calothrix and Richelia (from time points 1 and $12 \mathrm{~h}$, respectively) cells were analyzed in the short-term experiments of July 2009 as these were consistently observed with microscopy. In addition, a large group (19 cells) of Crocosphaera cells were also analyzed from the $12 \mathrm{~h}$ time point sample to provide a comparison measure for the Crocosphaera cells living symbiotically with Climacodium. The number of cell replicates for analysis at each time point was limited by the low cell abundances of the symbioses and free-living cells (Richelia, Calothrix and Crocosphaera) at the time of collection. Multiple planes $(>50)$ were recorded to assure a considerable robustness of the single-cell rate measurements.

NanoSIMS analysis was performed using a Cameca NanoSIMS $50 \mathrm{l}$ instrument following previously described methods (Musat et al., 2008). Briefly, samples were rastered with $16 \mathrm{keV}$ Cesium $\left(\mathrm{Cs}^{+}\right)$primary ions with current between 1-3 pA. Primary ions were focused into nominal $\sim 120 \mathrm{~nm}$ spot diameter. Mass resolving power in all measurements was $>6000$. The primary ion beam was used to raster the analyzed area with $256 \times 256$ pixels over the chosen raster size with dwelling time 1 or $2 \mathrm{~ms}$ per pixel. Negative secondary ions were collected simultaneously in electron multiplier detectors.

All scans were corrected for drift of the beam and sample stage after acquisition. Isotope ratio image was created as ratio of a sum of total counts for each pixel over all recorded planes of the investigated isotope and the main isotope. Regions of interest (ROI) around cell structures were defined using the parallel epi-fluorescent image taken before nanoSIMS analyses together with secondary ion images. For each ROI, the ratios ${ }^{15} \mathrm{~N} /{ }^{14} \mathrm{~N}$ (for example, inferred from ${ }^{12} \mathrm{C}^{15} \mathrm{~N} /{ }^{12} \mathrm{C}^{14} \mathrm{~N}$ ) were calculated.
Calculations: biovolume, ${ }^{15} \mathrm{~N}$ assimilation rates, $\% N$ transfer, growth rate, excess $N$ assimilation, global $N$ contribution

Epi-fluorescent images taken before nanoSIMS analyses were used with Axioscope software (Zeiss Axiovision Rel 4.7.2, Zeiss) to estimate heterocyst and unicellular cyanobiont cell diameters, and the apical and trans-apical dimensions of the Hemiaulus diatoms. As the cells were fixed and dried to the filters and the depth ( $\mathrm{Z}$ plane) was not visible under the microscope, we assumed that the height of the Hemiaulus, Chaetoceros and Climacodium cells was the same as the diameter of their respective symbiont's heterocyst or unicellular cell diameter.

Measurements of cell diameter, apical and transapical axes for the Hemiaulus and Chaetoceros cells were used in a biovolume estimate for an elliptic prism and four cones (23-SL) and a prism on an elliptic base $(29-\mathrm{H})$ as described by Sun and Liu (2003). Similar measures for the Climacodium cells were made in a biovolume estimate for a box plus a prism on a triangle base (30-H; Sun and Liu, 2003). The volume for the Crocosphaera cells (free-living and symbiotic) and the vegetative and heterocyst cells of Richelia and Calothrix was estimated by using the equation for a sphere (Sun and Liu, 2003). C content was calculated for the diatoms and symbionts, using the Strathmann (1967) equations, where the biovolume $(V)$ was used in place of plasma volume. The $\mathrm{C}$ content was then used to estimate nitrogen $(\mathrm{N})$ content by assuming a Redfield ratio of 6.6 (Redfield, 1934). As none of the symbiotic diatoms have been brought into pure culture, and at the time of our incubations cell densities were too low for standard elemental analysis, we considered our estimate of the initial $\mathrm{N}$ content based on biovolume and Redfield ratio as conservative and a reasonable alternative.

Nitrogen assimilation for individual symbiotic cells (fmol $\mathrm{N}$ per cell) were estimated by: assimilation $=\left[{ }^{15} \mathrm{~N}_{\mathrm{ex}} \times \mathrm{N}_{\mathrm{con}}\right] / \mathrm{N}_{\mathrm{sr}}$. The ${ }^{15} \mathrm{~N}_{\mathrm{ex}}$ is the mean of the ${ }^{15} \mathrm{~N} /{ }^{14} \mathrm{~N}$ ratios of the individual ROIs from the diatoms corrected for by the mean value of the ${ }^{15} \mathrm{~N} /{ }^{14} \mathrm{~N}$ ratios in diatoms of the time zero samples and divided by 100; the $\mathrm{N}_{\text {con }}$ is the $\mathrm{N}$ content estimated by $V$ and the Strathmann (1967) equations as described above, and $\mathrm{N}_{\mathrm{sr}}$ is the calculated atom percent $(\mathrm{AT} \%)$ of ${ }^{15} \mathrm{~N}$ in the experimental bottle according to Zehr and Montoya (2007). The assimilated $\mathrm{N}$ was divided by incubation time to determine cell-specific $\mathrm{N}_{2}$ fixation rates (fmol $\mathrm{N}$ per cell $\mathrm{h}^{-1}$ ).

The percentage of fixed $\mathrm{N}$ transferred to the diatom partners was determined by dividing the $\mathrm{N}$ assimilated as calculated above by the sum of $\mathrm{N}$ assimilated into the diatom, vegetative cells and heterocysts and multiplying by 100 . Growth rate for the symbionts and diatom partners were estimated by the following, $V=1 / t\left(R_{(\mathrm{F})-} R_{(\mathrm{I})} / R_{(\mathrm{S})}-R_{(\mathrm{I})}\right)$, where $t$ is time, the $R_{(\mathrm{F})}$ is estimated from mean value of the ROIs (for diatom and symbiont separately) at 
specific time points, the $R_{(\mathrm{I})}$ is the mean $\mathrm{AT} \%$ of the ROIs for the diatom or symbiont in the time zero samples, and the $R_{(\mathrm{S})}$ is the calculated $\mathrm{AT} \%$ of ${ }^{15} \mathrm{~N}$ in the experimental bottle according to Zehr and Montoya (2007).

To determine the percent of $\mathrm{N}$ fixed by the Richelia that was in excess of their own growth requirement and the percent of the diatom partner's growth supported by Richelia, we assumed growth rates for Hemiaulus and Richelia to be equivalent to that reported by Villareal $(1989,1990)$. These were 0.77 and 0.67 division per day, respectively, and we converted these to specific growth rate, $K^{\prime}$, by $K^{\prime}=$ division per day $\times \operatorname{Ln} 2$. These assumed values were also within the range we estimated for growth of both the Richelia and the Hemaiulus, which is described above (Table 1). We estimated the percent of the diatom's growth requirement supported by the Richelia by the following, (assimilation/ $\left.\left(\mathrm{N}_{\text {con }} \times K^{\prime}\right)\right) \times 100$, where assimilation is estimated as described above, $\mathrm{N}_{\text {con }}$ is $\mathrm{N}$ content estimated from $V$ and Strathmann (1967) equations, and $K^{\prime}$ is the assumed growth rate. The percentage of excess $\mathrm{N}$ fixed by the Richelia was calculated by the total $\mathrm{N}$ assimilated (host, vegetative cells and heterocysts) normalized to incubation time divided by the $\mathrm{N}_{\text {con }}$ of the symbiont multiplied by assumed growth rate (0.67 division per day).

Table 1 Summary of nanoSIMS analyses, cell dimensions and estimates of $\mathrm{N}_{2}$ fixation rates and growth rates

\begin{tabular}{|c|c|c|c|c|c|c|}
\hline Diatom symbiont & Time & $\begin{array}{c}\text { ROIs } \\
(n)\end{array}$ & $\begin{array}{c}A T \% \\
\left({ }^{15} N^{14} N\right)\end{array}$ & $\begin{array}{l}\text { Biovolume } \\
\quad\left(\mu \mathrm{m}^{3}\right)\end{array}$ & 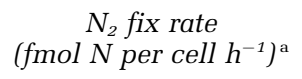 & $\begin{array}{c}\text { Growth rate } \\
\text { (division per day) }\end{array}$ \\
\hline Hemiaulus & \multirow{5}{*}{0.5} & 3 & 0.3789 & $4.22 \times 10^{3}$ & \multirow{5}{*}{21.0} & 0.22 \\
\hline Heterocyst 1 & & 1 & 0.3726 & 164 & & \\
\hline Vegetative & & 1 & 0.3790 & 8.72 & & 0.22 \\
\hline Heterocyst 2 & & 1 & 0.3812 & 37.4 & & \\
\hline Vegetative & & 1 & 0.3806 & 16.4 & & 0.23 \\
\hline Hemiaulus & \multirow{3}{*}{1} & 3 & 0.3651 & $3.49 \times 10^{3}$ & \multirow{3}{*}{5.88} & 0.06 \\
\hline Heterocyst & & 1 & 0.3761 & 102 & & \\
\hline Vegetative & & 2 & 0.3607 & 8.32 & & 0.05 \\
\hline Hemiaulus & \multirow{3}{*}{1} & 4 & 0.3759 & $1.87 \times 10^{3}$ & \multirow{3}{*}{8.94} & 0.10 \\
\hline Heterocyst & & 1 & 0.3764 & 85.1 & & \\
\hline Vegetative & & 2 & 0.3737 & 15.5 & & 0.09 \\
\hline Hemiaulus & \multirow{3}{*}{1} & & 0.3595 & $1.91 \times 10^{3}$ & \multirow{3}{*}{2.90} & 0.03 \\
\hline Heterocyst & & 1 & 0.3623 & 34.3 & & \\
\hline Vegetative & & 2 & 0.3657 & 8.62 & & 0.06 \\
\hline Hemiaulus & \multirow{4}{*}{3} & 6 & 0.4378 & $4.63 \times 10^{3}$ & \multirow{4}{*}{9.45} & 0.11 \\
\hline Heterocyst & & 1 & 0.4238 & 50.0 & & \\
\hline Vegetative & & 3 & 0.4362 & 6.0 & & \\
\hline Heterocyst & & 1 & 0.4508 & 45.6 & & 0.10 \\
\hline Hemiaulus & \multirow{4}{*}{3} & 8 & 0.4576 & $4.23 \times 10^{3}$ & \multirow{4}{*}{10.6} & 0.13 \\
\hline Heterocyst 1 & & 1 & 0.4104 & 72.3 & & \\
\hline Vegetative & & 2 & 0.4792 & 29.6 & & 0.16 \\
\hline Heterocyst 2 & & 1 & 0.4706 & 44.9 & & \\
\hline Hemiaulus & \multirow{5}{*}{3} & 6 & 0.4523 & $4.32 \times 10^{3}$ & \multirow{5}{*}{10.3} & 0.12 \\
\hline Heterocyst 1 & & 1 & 0.4118 & 41.1 & & \\
\hline Vegetative & & 1 & 0.4951 & 11.7 & & 0.10 \\
\hline Heterocyst 2 & & 1 & 0.4596 & 55.0 & & \\
\hline Vegetative & & 1 & 0.4485 & 13.4 & & 0.11 \\
\hline Hemiaulus & \multirow[t]{2}{*}{12} & 5 & 0.4739 & $1.56 \times 10^{3}$ & \multirow[b]{2}{*}{1.41} & 0.04 \\
\hline Heterocyst & & 1 & 0.4572 & 13.1 & & \\
\hline Hemiaulus & \multirow{3}{*}{12} & 5 & 0.4519 & $1.49 \times 10^{3}$ & \multirow{3}{*}{1.15} & 0.04 \\
\hline Heterocyst & & 1 & 0.4826 & 10.4 & & \\
\hline Vegetative & & 2 & 0.4748 & 5.77 & & 0.04 \\
\hline \multicolumn{6}{|l|}{ FL Calothrix } & \\
\hline Heterocyst & \multirow[t]{2}{*}{1} & 1 & 0.3570 & 35.8 & \multirow[t]{2}{*}{0.17} & 0.06 \\
\hline Vgetative & & 6 & 0.3679 & 28.5 & & \\
\hline \multicolumn{6}{|l|}{ FL Richelia } & \\
\hline Heterocyst & \multirow[t]{2}{*}{12} & 1 & 0.4575 & 44.5 & \multirow[t]{2}{*}{0.12} & \\
\hline Vegetative & & 6 & 0.7415 & 45.1 & & 0.11 \\
\hline FL Crocosphaera & 12 & 19 & $0.3561-0.4519$ & $65-2.66 \times 10^{2}$ & $0.02-2.39$ & $0.001-0.15$ \\
\hline
\end{tabular}


Table 1 (Continued)

\begin{tabular}{|c|c|c|c|c|c|c|}
\hline Diatom symbiont & Time & $\begin{array}{l}\text { ROIs } \\
\text { (n) }\end{array}$ & $\begin{array}{c}A T \% \\
\left({ }^{15} N /{ }^{14} N\right)\end{array}$ & $\begin{array}{l}\text { Biovolume } \\
\quad\left(\mu \mathrm{m}^{3}\right)\end{array}$ & $\begin{array}{c}N_{2} \text { fix rate } \\
\left(\text { fmol } N \text { per cell } h^{-1}\right)^{a}\end{array}$ & $\begin{array}{c}\text { Growth rate } \\
\text { (division per day) }\end{array}$ \\
\hline Hemiaulus & & 3 & 0.4032 & $2.39 \times 10^{4}$ & & \\
\hline Heterocyst 1 & 0 & 1 & 0.3632 & $9.10 \times 10^{2}$ & & \\
\hline Heterocyst 2 & & 1 & 0.3951 & $3.17 \times 10^{2}$ & & \\
\hline Hemiaulus & & 3 & 0.3494 & $2.84 \times 10^{4}$ & & \\
\hline Heterocyst 1 & & 1 & 0.3689 & $6.84 \times 10^{2}$ & & \\
\hline Heterocyst 2 & 0 & 1 & 0.3743 & $4.37 \times 10^{2}$ & & \\
\hline vegetative & & 1 & 0.3617 & $2.34 \times 10^{2}$ & & \\
\hline Hemiaulus & & 4 & 4.4440 & $4.41 \times 10^{3}$ & & 0.43 \\
\hline Heterocyst & 24 & 1 & 1.7900 & 75.3 & 47.8 & \\
\hline Vegetative & & 2 & 4.4600 & 18.9 & & 0.43 \\
\hline Hemiaulus & & 3 & 4.6600 & $3.12 \times 10^{3}$ & & 0.45 \\
\hline Heterocyst & 24 & 1 & 2.6810 & 71.0 & 38.7 & \\
\hline Vegetative & & 3 & 4.7430 & 27.4 & & 0.46 \\
\hline Hemiaulus & & 6 & 4.5960 & $4.31 \times 10^{3}$ & & 0.45 \\
\hline Heterocyst 1 & & 1 & 4.7068 & 38.7 & 48.7 & \\
\hline Vegetative & 24 & 1 & 4.7815 & 7.37 & & 0.47 \\
\hline Heterocyst 2 & & 1 & 4.9327 & 48.6 & & \\
\hline Vegetative & & 2 & 4.9693 & 28.8 & & 0.49 \\
\hline Hemiaulus & & 4 & 3.1628 & $2.12 \times 10^{3}$ & & 0.15 \\
\hline heterocyst 1 & & 1 & 3.1141 & 39.1 & 9.43 & \\
\hline vegetative & 48 & 2 & 3.8720 & 41.6 & & 0.18 \\
\hline heterocyst 2 & & 1 & 3.9909 & 35.8 & & \\
\hline Hemiaulus & & 3 & 3.0170 & $4.30 \times 10^{3}$ & & 0.14 \\
\hline Heterocyst & 48 & 1 & 3.4009 & 41.9 & 15.3 & \\
\hline Vegetative & & 4 & 3.5284 & 23.4 & & 0.17 \\
\hline Hemiaulus & & 3 & 3.0506 & $4.68 \times 10^{3}$ & & 0.14 \\
\hline Heterocyst & 48 & 1 & 3.6647 & $12.1 \times 10^{1}$ & 16.5 & \\
\hline Vegetative & & 3 & 3.5281 & 16.6 & & 0.33 \\
\hline Hemiaulus & & 4 & 9.7529 & $4.40 \times 10^{3}$ & & 0.48 \\
\hline Heterocyst 1 & & 1 & 9.8114 & 74.0 & 50.4 & \\
\hline Vegetative & 76 & 1 & 10.655 & 14.0 & & 0.48 \\
\hline Heterocyst 2 & & 1 & 11.652 & 68.9 & & \\
\hline Vegetative & & 1 & 11.891 & 33.2 & & 0.59 \\
\hline Hemiaulus & & 3 & 9.6706 & $4.33 \times 10^{3}$ & & 0.48 \\
\hline Heterocyst & 76 & 1 & 3.1086 & 94.8 & 49.2 & \\
\hline Vegetative & & 1 & 9.0384 & 41.6 & & 0.44 \\
\hline Chaetoceros & & 12 & 0.3593 & $\mathrm{~nm}$ & & \\
\hline Heterocyst 1 & & 1 & 0.3056 & 11.9 & & \\
\hline Vegetative & 0 & 13 & 0.3339 & 29.6 & & \\
\hline Heterocyst 2 & & 1 & 0.3417 & 15.6 & & \\
\hline Vegetative & & 5 & 0.3398 & 44.0 & & \\
\hline Chaetoceros & & 3 & 7.6500 & $2.17 \times 10^{4}$ & & 0.38 \\
\hline Heterocyst 1 & & 1 & 4.3552 & 91.3 & 71.5 & \\
\hline Vegetative & 76 & 3 & 7.0634 & 67.0 & & 0.35 \\
\hline Heterocyst 2 & & 1 & 6.5394 & 70.9 & & \\
\hline Vegetative & & 10 & 6.9387 & 66.7 & & 0.32 \\
\hline Climacodium & 0 & 2 & 0.3797 & $\mathrm{~nm}$ & & \\
\hline Crocosphaera & & 4 & 0.3710 & 55.9 & & \\
\hline Climacodium & 76 & 11 & 3.1657 & $1.56 \times 10^{5}$ & 6.03 & 0.37 \\
\hline Crocosphaera & & 28 & 5.3341 & 65.4 & 1.62 & 0.26 \\
\hline
\end{tabular}

Abbreviations: AT\%, atom percent; FL, free living (non-symbiotic); nanoSIMS, nanometer scale secondary ion mass spectrometry; nm, not measured; ROIs, regions of interests.

${ }^{a} \mathrm{~N}_{2}$ fixation rates were normalized by number of $\mathrm{N}_{2}$-fixing cell. 

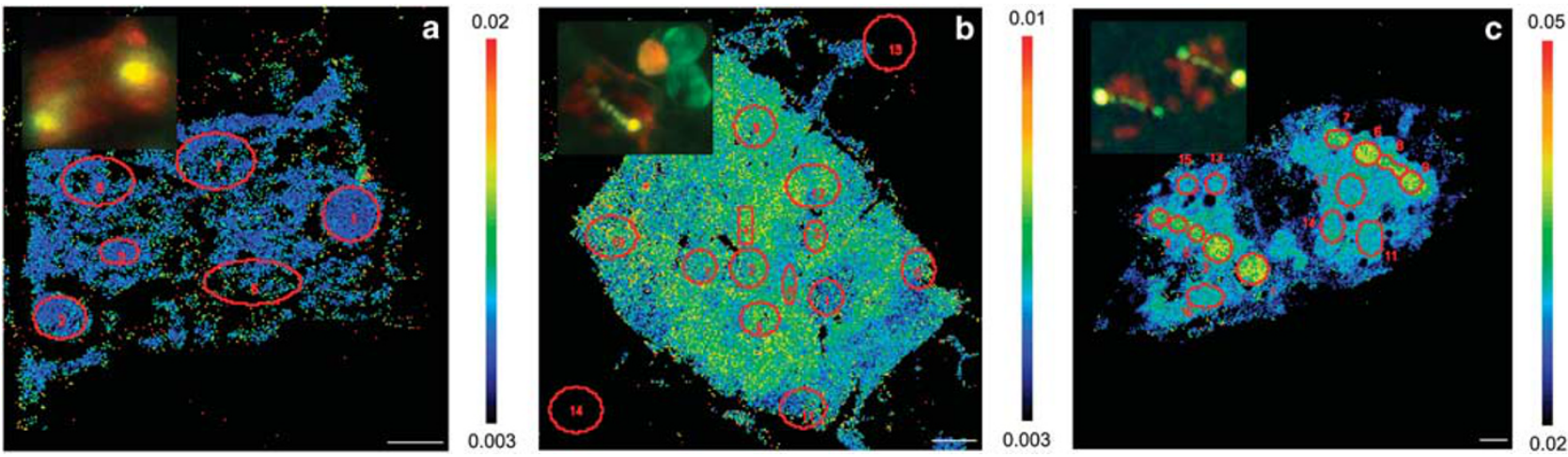

Figure 2 The images of ${ }^{15} \mathrm{~N} /{ }^{14} \mathrm{~N}$ ratios are shown for symbiont-containing Hemiaulus. The ${ }^{15} \mathrm{~N} /{ }^{14} \mathrm{~N}$ ratio is shown for Hemiaulus-Richelia symbioses at time 0 (a), $30 \mathrm{~min}(\mathbf{b})$ and $48 \mathrm{~h}$ (c). Inset panels a-c are the epi-fluorescent images taken before the nanoSIMS analyses. The numbers and markings in the figure define regions of interest, which were used for calculating ${ }^{15} \mathrm{~N} /{ }^{14} \mathrm{~N}$ ratios. Scale bars are $5 \mu \mathrm{m}$.

To estimate the contribution of the various symbiotic diatoms to basin scale $\mathrm{N}_{2}$ assimilation, we used non-bloom cell abundances reported for the Atlantic (39 cells $1^{-1}$; Carpenter et al., 1999) and the Pacific (80 cells $\mathrm{l}^{-1}$, Venrick 1974; Mague et al., 1974), the range in $\mathrm{N}_{2}$ assimilation determined from our nanoSIMS analyses of all the symbiotic cells, a domain of 17.8 and $27.8 \mathrm{~km}^{2} \times 10^{6}$ for the Atlantic and Pacific Oceans, respectively (Gruber and Sarmiento, 1997; Mahaffey et al., 2005; Carpenter and Capone, 2008), and 365 days of activity (12 h per day) to a depth of $10 \mathrm{~m}$.

\section{Results and discussion}

Bulk SW samples from two regions of the Pacific Ocean were incubated with ${ }^{15} \mathrm{~N}_{2}$ to trace and quantify the $\mathrm{N}_{2}$ fixation by cyanobacterial symbionts of various diatom genera at the cellular level. As diatoms are not able to acquire $\mathrm{N}$ from $\mathrm{N}_{2}$, they rely on extracellular dissolved fixed inorganic nitrogen pools (nitrate and ammonium), which in the open ocean surface waters are present at extremely low concentrations. Thus, the diatoms housing symbiotic diazotrophs have a distinct advantage if they can acquire the $\mathrm{N}_{2}$ fixed by their cyanobacterial partners. The nanoSIMS approach made it possible to visualize and quantify the ${ }^{15} \mathrm{~N}$ fixed in the symbionts and transferred to the diatom cells (Figures 2 and 3). In addition, the cyanobacterial partners were fully supporting the diatom $\mathrm{N}$ requirements for growth, as we always observed equal or higher enrichment in the diatoms than in the vegetative cells.

In the initial set of experiments, the ${ }^{15} \mathrm{~N}$ enrichment pattern within a chain of Hemiaulus cells clearly mirrored the location of two associated Richelia trichomes imaged before the analyses with epifluorescence microscopy (Figure 2), showing that the cyanobacteria fixed N. In addition, in areas identified as the diatom chloroplasts (that is, excited red in the epi-fluorescence image) were also enriched, suggesting that $\mathrm{N}$ was transferred from symbiont to diatom partner. Similarly, substantial
${ }^{15} \mathrm{~N}$ labeling was observed in the Calothrix heterocyst and vegetative cells and also in the Chaetoceros diatoms, suggesting that $\mathrm{N}$ was transferred along the trichome of the symbiont, and in addition, across the cell membrane of the diatom partner (Figure 3a). The ${ }^{15} \mathrm{~N}$ enrichment was most obvious in $<1 \mu \mathrm{m}$ diameter 'hotspots' inside the Crocosphaera cells found associated with the Climacodium diatoms (Figure 3c). In the Chaetoceros and Climacodium symbioses $\mathrm{N}_{2}$ fixation had not been previously demonstrated. In general, the transfer of fixed $\mathrm{N}$ to the diatom partners in all of the diatom-cyanobacterial symbioses had previously been assumed and had never been demonstrated. The nanoSIMS results directly prove that the $\mathrm{N}_{2}$-fixing cyanobionts provide fixed $\mathrm{N}$ to their diatom partners.

The transfer and incorporation of $\mathrm{N}$ from the cyanobacteria to the diatom cells was faster than the length of the sampling period in the initial set of experiments (24-76 h). Diatoms, and other cells in oligotrophic oceans are often assumed to grow slowly due to low ambient nutrient concentrations, and thus we anticipated that the symbiont would only transfer a fraction of the $\mathrm{N}_{2}$ fixed to the diatom partner within the incubation. However, in our longterm experiments, the enrichment was high after $24 \mathrm{~h}$ (Figure 4a) and we were not able to estimate the $\mathrm{N}$ transfer over the shorter time interval. In our subsequent short-term experiments, we observed elevated ${ }^{15} \mathrm{~N}$ enrichment in Hemiaulus cells incubated for as short as $30 \mathrm{~min}$ and as the range of enrichment was similar in the cells measured after 3 and $12 \mathrm{~h}$ incubations, it appears that $\mathrm{N}$ transfer saturated by $3 \mathrm{~h}$ (Figure 4b). The near saturation within $3 \mathrm{~h}$ was much faster than anticipated, and means that measured fixation rates may be underestimated. We expected that the transfer would be slow, as the symbionts reside external to the diatom cell membrane. The Richelia symbionts reside between the frustule and the cell membrane (plasmalemma) of the Hemiaulus diatom cell wall (Janson et al., 1995), whereas the Calothrix symbionts are extracellular on the Chaetoceros diatom 

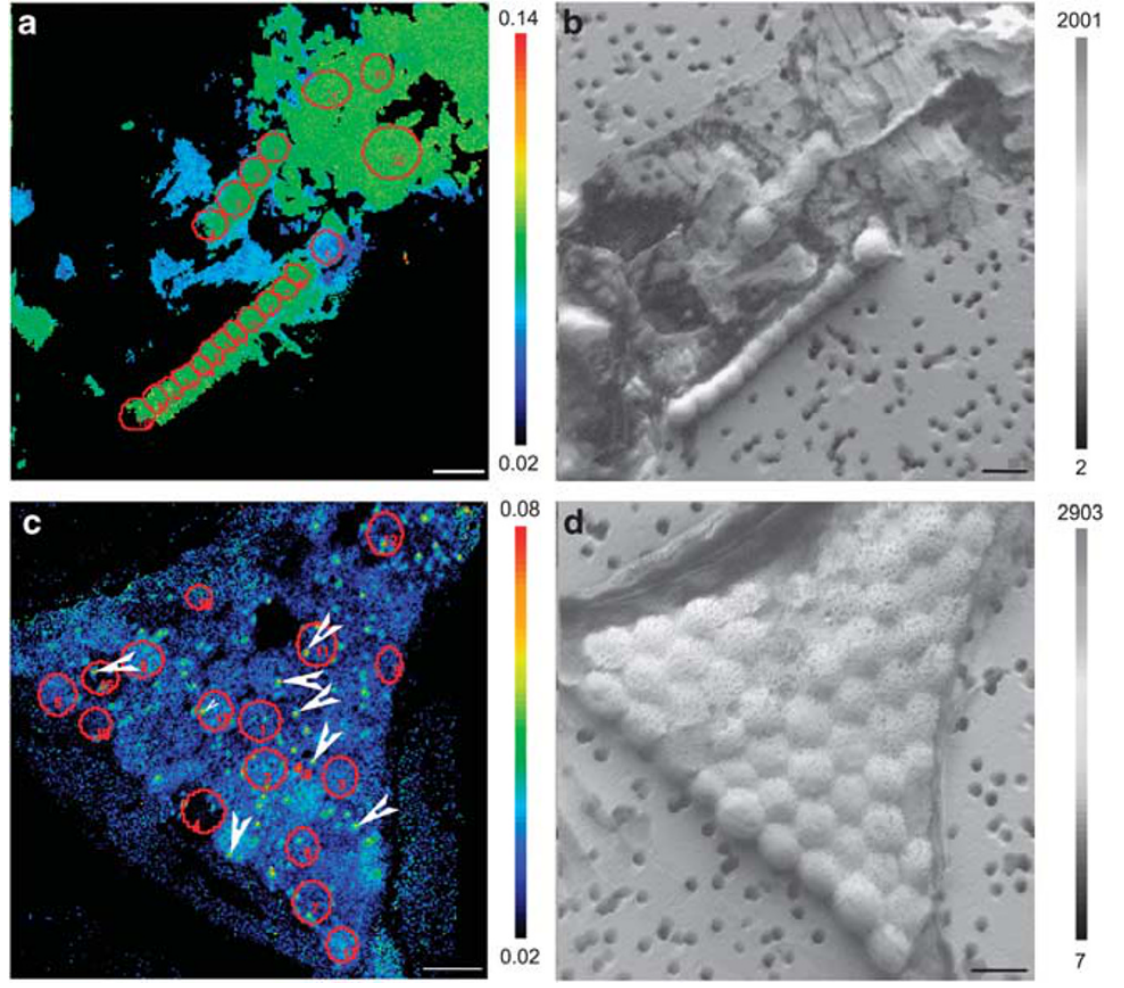

Figure 3 The images of ${ }^{15} \mathrm{~N} /{ }^{14} \mathrm{~N}$ ratios are shown for Chaetoceros-Calothrix and the Climacodium-cyanobiont symbioses. The ${ }^{15} \mathrm{~N} /{ }^{14} \mathrm{~N}$ ratio is shown in A and C for Chaetoceros-Calothrix and the Climacodium-Crocosphaera symbioses, respectively. Note the 'hotspots' (white arrows) of enrichment within the individual cyanobiont (Crocosphaera) cells of Climacodium (c). The corresponding total ion content images images for the same symbioses in $\mathbf{a}$ and $\mathbf{c}$ are shown in $\mathbf{b}$ and $\mathbf{d}$, respectively. The numbers and markings in the Figure define regions of interest, which were used for calculating ${ }^{15} \mathrm{~N} /{ }^{14} \mathrm{~N}$ ratios. Scale bars are $5 \mu \mathrm{m}$.

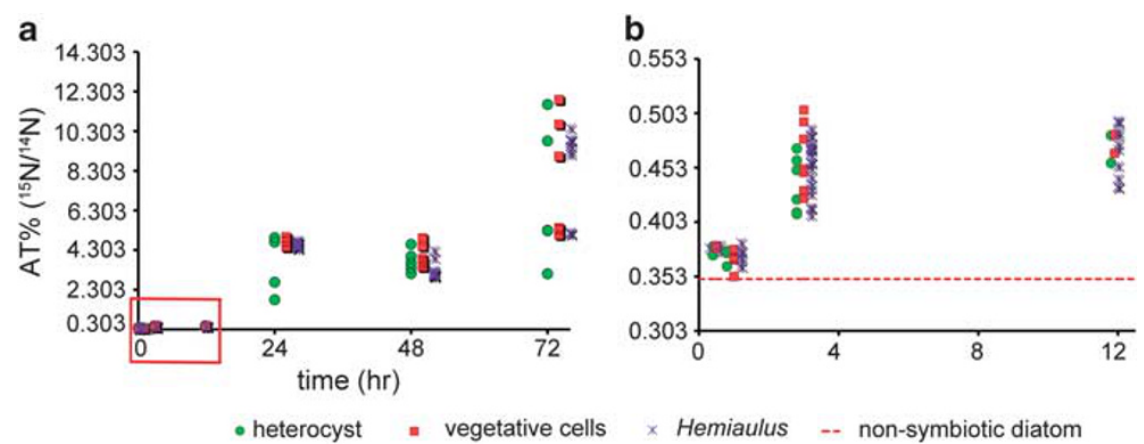

Figure 4 Summary of results from nanoSIMS analysis. (a) The atom $\%$ of the ${ }^{15} \mathrm{~N} /{ }^{14} \mathrm{~N}$ ratios for ROIs of individual Hemiaulus-Richelia are shown as a function of incubation time in both long and short-term experiments. (b) The atom $\%$ of the ${ }^{15} \mathrm{~N} /{ }^{14} \mathrm{~N}$ ratios for ROIs of individual Hemiaulus-Richelia symbioses from the short-term experiments and represents the values within the red box shown in a. Note that the Richelia enrichment values are given as ratios estimated in the heterocyst and the vegetative cells. The dashed red line indicates the value for a co-occurring non-symbiotic diatom.

(Norris, 1961), and the cyanobiont (Crocosphaera) location is unknown in the Climacodium symbioses. The $\mathrm{N}$ transfer we observed along the trichomes of symbiotic and free-living Richelia and Calothrix was not unexpected, as rapid transfer has already been reported for lab cultures of free-living filamentous heterocystous cyanobacteria (Wolk et al., 1976; Ropa et al., 2007; Ploug et al., 2010). Unique to the results presented here, is that the $\mathrm{N}$ transferred along the symbiotic trichome (heterocyst to vegetative cells) is also transferred across the diatom cell membrane.

In terrestrial systems, rapid nutrient transfer is facilitated by the intracellular location of the symbionts within specialized tissues or organs of multicellular hosts, which are connected to the host tissues via vesicles (Rai et al., 2000). Nitrogen should be easily transferred from intracellular symbionts, but it is unknown how $\mathrm{N}$ transfer is facilitated in these planktonic diatom symbioses. 
The orientation of the Calothrix heterocyst attached to the intercalary spaces of their Chaetocoeros partners may facilitate the transfer of $\mathrm{N}$ to the diatom while still exposing the trichome to the surrounding environment (for light and to acquire other nutrients). The efficiencies of nutrient exchange are poorly resolved in most symbioses (Rai et al., 2000), and the mechanisms in these simple unicellular symbioses may be very different from symbiotic systems with multicellular hosts.

As the ${ }^{15} \mathrm{~N}$ labeling could be measured on entire individual cells (symbioses), cell-specific rates of $\mathrm{N}_{2}$ fixation could be calculated for the natural populations (Table 1). Using the ratios obtained from the nanoSIMS analyses, we obtained remarkably similar rates of $\mathrm{N}_{2}$ assimilation (range, $1.15-71.5 \mathrm{fmol} \mathrm{N}$ per cell $\mathrm{h}^{-1}$ ) amongst all the symbioses, including the unicellular Crocosphaera symbionts of Climacodium (1.62 fmol $\mathrm{N}$ per cell $\mathrm{h}^{-1}$ ). Our rates were also comparable with the cellular rates previously estimated from bulk $\mathrm{N}_{2}$-fixation rates for a large expansive mono-specific bloom of Richelia associated with Hemiaulus hauckii in the North Atlantic Ocean $\left(50 \mathrm{fmol} \mathrm{N}\right.$ per cell $\mathrm{h}^{-1}$; Carpenter et al., 1999). This result is surprising given that the symbioses differ in diatom association (that is, Hemiaulus, Chaetoceros and Climacodium), diatom cell size $\left(1.49 \times 10^{3}\right.$ to $\left.1.56 \times 10^{5} \mu \mathrm{m}^{3}\right)$ collection (different ocean basins and during different years), incubation time $(30 \mathrm{~min}-76 \mathrm{~h})$ and cell densities (bloom versus background abundances).

The ${ }^{15} \mathrm{~N} /{ }^{14} \mathrm{~N}$ ratios determined on the individual symbiotic cells by nanoSIMS were also used to estimate growth of the symbionts and the diatoms (see Materials and methods). We determined remarkably similar growth rates for all three symbiotic cell types and their respective diatom partners. The estimates of growth rate for the field collected Hemiaulus (0.04-0.48 division per day) were similar to those ( 0.77 division per day) reported for laboratory cultures of another symbiotic diatom, Rhizosolenia clevi (Villareal, 1990), which associates with a closely related Richelia strain of Hemiaulus (Janson et al., 1999; Foster and Zehr, 2006). It should be noted that $R$. clevi are much larger in cell length than the Hemiaulus reported here. The other two symbionts, including the unicellular Crocosphaera cells associated with Climacodium, were also similar (0.38-0.51 per division) to the growth rates of Richelia, which was equally surprising given the same reasons aforementioned and additionally, differing cell types of the symbionts (that is, unicellular and heterocystous).

In several of the symbioses (14 of 19) analyzed with nanoSIMS, the estimated growth rates for symbiont and diatom partners were so similar that a synchronous division would be expected (Table 1). In addition, our results indicate that the co-occurring free-living Richelia and Calothrix cells had substantially reduced growth rate compared with the same symbiont cell types living in association with the diatoms (Table 1). The average rate of $\mathrm{N}_{2}$ fixation (20.4 and $71.5 \mathrm{fmol} \mathrm{N}$ per cell $\mathrm{h}^{-1}$ ) for the symbiotic heterocystous cells (Richelia and Calothrix, respectively) is 170-420 times higher than the $\mathrm{N}_{2}$ fixation rate $(0.12$ and $0.17 \mathrm{fmol} \mathrm{N}$ per cell $\mathrm{h}^{-1}$, respectively) estimated for free-living Richelia and Calothrix cells (Table 1). In terrestrial symbiotic systems, cyanobionts undergo several structural-functional changes, including modifications to their growth rates and metabolism, which is often coordinated by the host to maximize nutrient transfer and balanced growth amongst the partners (Rai et al., 2000). A similar scenario may exist in these marine symbioses as a means to provide sufficient $\mathrm{N}$ for both partners.

As we demonstrated that $\mathrm{N}$ was transferred, and growth and $\mathrm{N}_{2}$ fixation rates were apparently accelerated under symbiotic conditions, we were curious whether the symbionts were fixing more $\mathrm{N}$ than required for their growth (see Materials and methods). Assuming similar growth rates for the Hemiaulus and the Richelia, as was observed in our experiments, we estimate that Richelia symbionts fix between 71 and $651 \%$ more $\mathrm{N}$ than required for their own growth (see Materials and methods). Other cyanobacteria, that is, free-living Trichodesmium (Mulholland et al., 2004), also fix more $\mathrm{N}$ than required for their own growth, but unique to the symbioses studied here, is that up to $97.3 \%$ of the total fixed $\mathrm{N}$ is transferred to their diatom partners and not assimilated by the symbionts themselves nor simply released to the environment. Given that $\mathrm{N}_{2}$ fixation is energetically expensive and highly regulated (Postgate, 1972), we suspect that the diatoms may influence the $\mathrm{N}$ metabolism of the symbionts.

Determining the contribution of these fragile associations to global $\mathrm{N}$ (and $\mathrm{C}$ ) has been difficult to predict. We used the cell-specific rates of $\mathrm{N}_{2}$ fixation determined by nanoSIMS analysis to estimate basin scale $\mathrm{N}_{2}$ assimilation attributed to the symbioses (see details in Materials and methods). We estimated that the symbiotic diatom populations (0.19 and 0.62 Tmol $\mathrm{N}$ per year in Atlantic and Pacific Oceans, respectively) could be an equally important source of new $\mathrm{N}$ as the free-living colonial diazotroph, Trichodesmium (0.36-0.71 Tmol N per year; Capone et al., 2008), which is usually considered largely responsible for $\mathrm{N}_{2}$ fixation in the open ocean. The densities of the symbioses are not easily detected and most data on the symbioses are reported during bloom densities, and as we are unable to measure the $\mathrm{N}$ release from the symbioses, our estimate is likely an underestimate. Moreover, recent evidence demonstrates that $\mathrm{N}_{2}$ fixation will be underestimated when the ${ }^{15} \mathrm{~N}_{2}$ tracer is introduced as a bubble (Mohr et al., 2010). Although conservative, our calculation reveals the importance of an often un-estimated pool of $\mathrm{N}$, and indicates that diatom symbioses should be included in global $\mathrm{N}$ models. 


\section{Acknowledgements}

A special acknowledgement to Dr F Prahl and Dr A White of OSU (OCE 0726422) and Dr B Popp of UH for inviting and sponsoring RAF on the cruise to Gulf of California. RAF is also grateful to the captains and crew of the R/V New Horizon and R/V Kilo Moana for assistance during sampling in July 2008. RAF and JPZ recognize the helpful suggestions and advice by J Montoya and C Mahaffey in the data processing and D Karl for his helpful suggestions on our manuscript preparation. We also thank two anonymous reviewers for their comments and helpful suggestions. Funding for salary support (RAF) and sample processing has been provided by the National Science Foundation Center for Microbial Oceanography: Research and Education, the Gordon and Betty Moore Foundation (JPZ) and National Science Foundation (RAF and JPZ). The Max Planck Society sponsored the nanoSIMS and irm-MS analyses.

\section{References}

Carpenter EJ, Capone DG. (2008). Nitrogen fixation in the marine environment. In: Capone DG, Bronk DA, Mulholland MR, Carpenter EJ (eds) Nitrogen in the Marine Environment. Academic Press: London, pp 141-198.

Carpenter EJ, Janson S. (2000). Intracellular symbionts in the marine diatom Climacodium frauenfeldianum Grunow. J Phycol 36: 540-544.

Carpenter EJ, Montoya JP, Burns JA, Mulholland M, Subramaniam A, Capone DG. (1999). Extensive bloom of a $\mathrm{N}_{2}$-fixing diatom/cyanobacterial association in the Tropical Atlantic Ocean. Mar Ecol Prog Ser 185: 273-283.

Clode PL, Stern RA, Marshall AT. (2007). Subcellular imaging of isotopically labeled carbon compounds in a biological sample by ion microprobe (NanoSIMS). Microsc Res Tech 70: 220-229.

Codispoti L. (1995). Is the ocean losing fixed nitrogen? Nature 376: 724.

Finzi-Hart JA, Pett-Ridge J, Weber PK, Popa R, Fallon SJ, Gunderson T et al. (2009). Fixation and fate of C and N in the cyanobacterium Trichodesmium using nanometer-scale secondary ion mass spectrometry. Proc Natl Acad Sci USA 106: 6345-6350.

Foster RA, O'Mullan GD. (2008). Nitrogen-fixing and nitrifying Symbioses in the marine environment. In: Capone DG, Bronk DA, Mulholland MR, Carpenter EJ (eds). Nitrogen in the Marine Environment. Academic Press: London, pp 1197-1218.

Foster RA, Zehr JP. (2006). Characterization of diatom-cyanobacteria symbioses on the basis of nifH, hetR, and 16S rRNA sequences. Environ Microbiol 8: 1913-1925.

Gruber N. (2005). A bigger nitrogen fix. Nature 436: 786-787.

Gruber N, Sarmiento J. (1997). Global patterns of marine nitrogen fixation and denitrification. Glob Biogeochem Cycles 11: 235-266.

Halm H, Musat N, Lam P, Langlois R, Musat F, Peduzzi S et al. (2009). Co-occurrence of denitrification and nitrogen fixation in a meromictic lake, Lake Cadagno (Switzerland). Environ Microbiol 11: 1945-1958.
Janson J, Rai AN, Bergman B. (1995). The intracelllar cyanobiont Richelia intracellularis : ultrastructure and immuno-localisation of phycoerythrin, nitrogenase, rubisco, and glutamine synthetase. Mar Biol 124: 1-8.

Janson S, Wouters J, Bergman B, Carpenter EJ. (1999). Host specificity in the Richelia-diatom symbioses revealed by hetR gene sequence analyses. Environ Microbiol 1: 431-438.

Karl D, Letelier R, Tupas L, Dore J, Christian J, Hebel D. (1997). The role of nitrogen fixation in biogeochemical cycling in the subtropical North Pacific Ocean. Nature 388: $533-538$.

Karl D, Michaels A, Bergman B, Capone DG, Carpenter EJ, Letelier $\mathrm{R}$ et al. (2002). Dinitrogen fixation in the world's oceans. Biogeochemistry 57/58: 47-98.

Lechene CP, Luyten Y, McMahon G, Distel DL. (2007). Quantitative imaging of nitrogen fixation by individual bacteria within animal cells. Science 317: 1563-1566.

Mague T, Weare N, Holm-Hansen O. (1974). Nitrogen fixation in the North Pacific Ocean. Mar Biol 24: 109-119.

Mahaffey C, Michaels AF, Capone DG. (2005). The conundrum of marine $\mathrm{N}_{2}$ fixation. Am J Sci 305: 546-595.

Michaels A, Olson D, Sarmiento J, Ammerman J, Fanning $\mathrm{K}$, Jahnke R et al. (1996). Inputs, losses and transformations of nitrogen and phosphorus in the pelagic North Atlantic Ocean. Biogeochemistry 35: 181-226.

Mohr W, Großkopf T, Wallace DRW, LaRoche J. (2010). Methodological underestimation of oceanic nitrogen fixation rates. PLoS One 9: 1-7.

Montoya J, Holl C, Zehr J, Hansen A, Villareal T, Capone DG. (2004). High rates of $\mathrm{N}_{2}$ fixation by unicellular diazotrophs in the oligotrophic Pacific Ocean. Nature 430: 1027-1032.

Mulholland M, Bronk DA, Capone DG. (2004). Dinitrogen fixation and release of ammonium and dissolved organic nitrogen by Trichodesmium IMS101. Aquat Microb Ecol 37: 85-94.

Musat N, Halm H, Winterholler B, Hoppe P, Peduzzi S, Hillion $\mathrm{F}$ et al. (2008). A single-cell view on the ecophysiology of anaerobic phototrophic bacteria. Proc Natl Acad Sci USA 105: 17861-17866.

Norris RE. 1961. Observations on phytoplankton organisms collected on the NZOI Pacific Cruise, September 1958. N Z J Sci 4: 162-168.

Ploug H, Musat N, Adam B, Moraru C, Lavik G, Vagner T et al. (2010). Carbon and nitrogen fluxes associated with the cyanobacterium Aphanizomenon sp. in the Baltic Sea. ISME J 4: 1215-1223.

Postgate J. (1972). Nitrogen Fixation. Cambridge University Press: Cambridge, UK.

Rai AN, Söderbäck E, Bergman B. (2000). Cyanobacteriumplant symbioses. New Phytol 147: 449-481.

Redfield AC. (1934). On the proportions of organic derivations in sea water and their relation to the composition of plankton. In: Daniel RJ (ed). James Johnstone Memorial Volume. University Press of Liverpool: UK, pp 177-192.

Römer W, Wu TD, Duchambon P, Amessou M, Carrez D, Johannes L et al. (2006). Sub-cellular localization of a ${ }^{15} \mathrm{~N}$-labelled peptide vector using NanoSIMS imaging. Appl Surface Sci 252: 6925-6930.

Ropa R, Weber PK, Pett-Ridge J, Finzi JA, Fallon ST, Hutcheon ID et al. (2007). Carbon and nitrogen fixation and metabolite exchange in and between individual cells of Anabaena oscillariodes. ISME J 1: 354-360. 
Stewart WDP. (1973). Nitrogen fixation by photosynthetic microorganisms. Ann Rev Microbiol 27: 283-316.

Strathmann RR. (1967). Estimating the organic carbon content of phytoplankton from cell volume or plasma volume. Limnol Oceanogr 12: 411-418.

Sun J, Liu D. (2003). Geometric models for calculating cell biovolume and surface area for phytoplankton. J Plank Res 25: 1331-1346.

Tomas CR. (1997). Identifying Marine Phytoplankton. Academic Press: San Diego, CA, USA.

Venrick E. (1974). The distribution and significance of Richelia intracellularis in the North Pacific cdentral gyre. Limnol Oceanogr 19: 437-445.

Villareal T. (1989). Division cycles in the nitrogen-fixing Rhizosolenia (Bacillariophyceae) Richelia (Nostocaceae) symbiosis. Br Phycol J 24: 357-365.

Villareal T. (1990). Laboratory culture and preliminary characterization of the nitrogen-fixing RhizosoleniaRichelia symbiosis. Mar Ecol 11: 117-132.

Villareal TA. (1994). Widespread occurrence of the Hemiaulus-cyanobacteria symbiosis in the southwest North Atlantic Ocean. Bull Mar Sci 54: 1-7.
Wolk CP, Thomas J, Shaffer PW, Austin SM, Galonsky A. (1976). Pathway of nitrogen metabolism after fixation of ${ }^{13} \mathrm{~N}$-labeled nitrogen gas by the cyanobacterium Anabaena cylindrical. J Biol Chem 251: 5027-5034.

Zehr JP, Carpenter EJ, Villareal T. (2000). New perspectives on nitrogen-fixing microorganisms in tropical and subtropical oceans. Trends Microbiol 8: 68-73.

Zehr JP, Mellon MT, Zani S. (1998). New nitrogen-fixing microorganisms detected in oligotrophic oceans by amplification of nitrogenase (nifH) genes. Appl Environ Microbiol 64: 3444-3450.

Zehr JP, Montoya JP. (2007). Measuring $\mathrm{N}_{2}$ fixation in the field. In: Bothe H, Ferguson SJ, Newton WE. (eds). Biology of the Nitrogen Cycle. Elsevier: Amsterdam, The Netherlands, pp 193-205.

(a) This work is licensed under the Creative

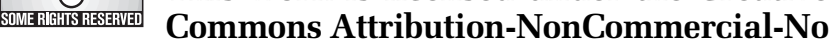

Derivative Works 3.0 Unported License. To view a copy of this license, visit http://creativecommons. org/licenses/by-nc-nd/3.0/ 